\title{
Senyawa Brusein-A dari Buah Makasar (Brucea javanica (L.) Merr.) sebagai Antiproliferasi terhadap Sel Kanker Payudara T47D
}

\author{
Subeki, ${ }^{1}$ Muhartono ${ }^{2}$ \\ ${ }^{1}$ Jurusan Teknologi Hasil Pertanian, Fakultas Pertanian, Universitas Lampung, ${ }^{2}$ Jurusan Pendidikan Dokter, \\ Fakultas Kedokteran, Universitas Lampung
}

\begin{abstract}
Abstrak
Pada saat ini, insidensi kanker payudara telah menempati urutan teratas pada wanita penderita kanker di negara berkembang termasuk Indonesia, sehingga pencarian obat yang lebih tepat masih diperlukan. Tujuan penelitian ini untuk menentukan aktivitas antiproliferasi senyawa brusein-A terhadap sel kanker payudara T47D secara in vitro. Brusein-A diisolasi dari buah makasar (Brucea javanica (L.) Merr.) dan struktur senyawa yang diperoleh dielusi dengan spektroskopi data. Aktivitas antikanker diamati sebagai antiproliferasi terhadap sel kanker payudara T47D. Antiproliferasi diuji dengan penambahan sulfo rodamin B pada media kultur sel. Masing-masing sumur mengandung 30.000 sel yang diberikan brusein-A dengan variasi 10 konsentrasi antara lain $0,04 \mu \mathrm{g} / \mathrm{mL}$, $0,08 \mu \mathrm{g} / \mathrm{mL}, 0,16 \mu \mathrm{g} / \mathrm{mL}, 0,31 \mu \mathrm{g} / \mathrm{mL}, 0,63 \mu \mathrm{g} / \mathrm{mL}, 1,25 \mu \mathrm{g} / \mathrm{mL}, 2,5 \mu \mathrm{g} / \mathrm{mL}, 5 \mu \mathrm{g} / \mathrm{mL}, 10 \mu \mathrm{g} / \mathrm{mL}, \mathrm{dan} 20 \mu \mathrm{g} / \mathrm{mL}$ selama 72 jam. Percobaan diulang dua kali dan selanjutnya persentase viabilitas sel dihitung. Hasil penelitian

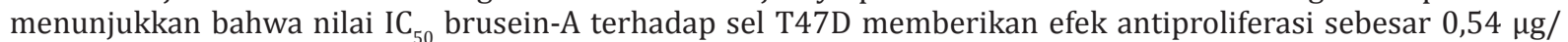
$\mathrm{mL}$ dengan cisplatin $0,43 \mu \mathrm{g} / \mathrm{mL}$ sebagai kontrol positif. Simpulan, brusein-A mempunyai aktivitas antiproliferasi terhadap sel kanker payudara T47D. [MKB. 2015;47(1):22-8]
\end{abstract}

Kata kunci: Antiproliferasi, buah makasar, Brucea javanica, brusein-A, sel kanker T47D

\section{Brucein-A Compound of Makasar Fruit (Brucea javanica (L.) Merr.) as Antiproliferative Agent against T47D Breast Cancer Cells}

\begin{abstract}
Breast cancer is currenly the number one cancer of all cancers attacking women, especially those who live in developing countries including Indonesia. Therefore, the pursuit of drugs for breast cancer is still needed. The aim of this study was to determine the anti proliferative activity of brucein-A against breast cancer T47D cells in vitro. Bruceine-A was isolated from "buah makasar" (Brucea javanica (L.) Merr) and the structure of the isolated compound was elucidated by spectral data. The activities of anticancer were evaluated from the antiproliferative effects on T47D breast cancer cell line. The antiproliferative effects were examined in cultured cells stained with sulforhodamin B. Each well contained 30,000 cells, which was treated with bruceine-A in 10 concentration variations of $0.04 \mu \mathrm{g} / \mathrm{mL}, 0.08 \mu \mathrm{g} / \mathrm{mL}, 0.16 \mu \mathrm{g} / \mathrm{mL}, 0.31 \mu \mathrm{g} / \mathrm{mL}, 0.63 \mu \mathrm{g} / \mathrm{mL}, 1.25 \mu \mathrm{g} / \mathrm{mL}, 2.5 \mu \mathrm{g} / \mathrm{mL}, 5 \mu \mathrm{g} / \mathrm{mL}, 10$ $\mu \mathrm{g} / \mathrm{mL}$, and $20 \mu \mathrm{g} / \mathrm{mL}$ for 72 hours. The experiment was replicated twice and the inhibitory percentage of cells was then calculated. The results showed that the IC50 value of bruceine-A on T47D cells as anantiproliferative effect was $0.54 \mu \mathrm{g} / \mathrm{mL}$ with cisplatin $0.43 \mu \mathrm{g} / \mathrm{mL}$ as the positive control. In conclusion, bruceine-A has an antiproliferative activity on T47 D breast cancer cell line. [MKB. 2015;47(1):22-8]
\end{abstract}

Key words: Antiproliferative, buah makasar, Brucea javanica, brucein-A, cancer T47D cell

Korespondensi: Muhartono, dr., Sp.PA, M. Kes, Fakultas Kedokteran Universitas Lampung, Jalan Soemantri Brojonegoro No.1, mobile 081272358340, e-mail: dmuhartono@yahoo.com 


\section{Pendahuluan}

Kanker payudara merupakan keganasan kedua yang sering ditemukan dan menjadi penyebab utama kematian pada wanita sesudah kanker serviks. ${ }^{1}$ Diperkirakan bahwa kanker payudara mencapai 23\% dari seluruh kasus kanker dan sekitar 14\% menyebabkan kematian. ${ }^{2}$ Insidens kanker payudara di Indonesia mencapai 37 per 100.000 penduduk yaitu dengan angka kematian sebesar 18,6\%. ${ }^{3}$ Berdasarkan laporan Aryandono dan Harijadi, ${ }^{4}$ bahwa dari 245 pasien kanker payudara terdiri atas $62 \%$ berusia $40-59$ tahun, $19 \%$ di bawah usia 40 tahun, dan $19 \%$ berusia lebih dari 60 tahun.

Pada umumnya pengobatan kanker payudara dilakukan dengan cara operasi, radiasi, terapi hormonal, dan juga kemoterapi. Penggunaan obat-obatan untuk kemoterapi tidak hanya mampu membunuh sel-sel kanker yang sedang membelah diri tetapi juga dapat membunuh sel sehat yang membelah diri seperti sel imun, sel sumsum tulang, sel mukosa usus, dan sel folikel rambut. ${ }^{5}$ Secara klinis efek samping kemoterapi mampu menyebabkan infeksi, mual, kelelahan, memar dan berdarah, anemia, rambut rontok, nafsu makan berkurang, mulut sakit, diare, mati rasa atau kesemutan, alergi, serta penggumpalan darah. ${ }^{6}$ Oleh karena itu, perlu dicari obat baru yang mampu menyembuhkan kanker payudara secara efektif, aman, dan kurang menimbulkan efek samping. Salah satu alternatif adalah dengan menggunakan senyawa brusein-A yang diisolasi dari buah makasar (Brucea javanica (L.) Merr.).

Tumbuhan buah makasar banyak dijumpai di negara Asia dan dikenal dengan nama ya dan zi. Tumbuhan ini berbentuk perdu tegak menahun dan banyak tumbuh liar di Indonesia di hutan atau di pekarangan rumah. Buah tanaman ini mempunyai rasa yang sangat pahit sehingga tidak dapat dikonsumsi dan sering digunakan sebagai obat tradisional untuk mencegah disentri, diare, dan malaria. Buah makasar banyak mengandung senyawa quasinoid dan mempunyai aktivitas sebagai antikanker. ${ }^{7,8}$ Golongan dari senyawa quasinoid mempunyai kemampuan untuk dapat menghambat nuclear factor kappa $B(\mathrm{NF}-\mathrm{\kappa B})$ dan berikatan dengan DNA sehingga menginduksi apoptosis atau kematian sel kanker. Selama apoptosis akan terjadi degradasi dan fragmentasi DNA menjadi rantai oligonukleosom sehingga sel kanker menjadi mati. ${ }^{9-11}$ Oleh karena itu, brusein-A yang merupakan senyawa quasinoid dari buah makasar kemungkinan besar dapat digunakan sebagai antikanker payudara.

Penelitian ini bertujuan untuk mengetahui aktivitas antikanker senyawa brusein-A yang diisolasi dari buah makasar terhadap sel kanker payudara T47D secara in vitro.

\section{Metode}

Penelitian dilaksanakan dari bulan April sampai Juni 2012 menggunakan desain ekperimental di laboratorium analisis hasil pertanian Jurusan Teknologi Hasil Pertanian Fakultas Pertanian Universitas Lampung. Selanjutnya, pengujian terhadap aktivitas antikanker dilaksanakan di laboratorium Puslit Kimia, LIPI, Bandung.

Penelitian dilakukan dalam dua kali ulangan dengan perlakuan konsentrasi brusein-A yang terdiri atas $0,04 \mu \mathrm{g} / \mathrm{mL}, 0,08 \mu \mathrm{g} / \mathrm{mL}, 0,16 \mu \mathrm{g} /$ $\mathrm{mL}, 0,31 \mu \mathrm{g} / \mathrm{mL}, 0,63 \mu \mathrm{g} / \mathrm{mL}, 1,25 \mu \mathrm{g} / \mathrm{mL}, 2,5$ $\mu \mathrm{g} / \mathrm{mL}, 5 \mu \mathrm{g} / \mathrm{mL}, 10 \mu \mathrm{g} / \mathrm{mL}$, dan $20 \mu \mathrm{g} / \mathrm{mL}$.

Senyawa brusein-A diekstraksi serta diisolasi sesuai dengan prosedur Subeki dkk. ${ }^{12}$ Sebanyak $10 \mathrm{~kg}$ tepung buah makasar direndam dalam $30 \mathrm{~mL}$ EtOH $70 \%$ selama 28 hari, selanjutnya filtrat disaring dengan kain saring dan diuapkan dengan menggunakan rotari evaporator menjadi 1 L. Filtrat pekat tersebut kemudian diekstrak dengan etil asetat (EtOAc) sehingga diperoleh fraksi air dan EtOAc. Fraksi EtOAc diuapkan hingga kering kemudian dimasukkan ke dalam silika gel kolom kromatografi dan juga dielusi dengan $\mathrm{CHCl}_{3}(1 \mathrm{~L}), \mathrm{MeOH}-\mathrm{CHCl}_{3}(3: 97,1 \mathrm{~L})$, dan $\mathrm{MeOH}-\mathrm{CHCl}_{3}(1: 4,1 \mathrm{~L})$ secara berurutan. Dengan cara yang sama dilakukan pengeringan fraksi $\mathrm{MeOH}-\mathrm{CHCl}_{3}$ (1:4) setelah itu dimasukkan ke dalam silika gel kolom kromatografi dan dielusi dengan heksan:EtOAc $(3: 7,4$ L) hingga diperoleh 10 fraksi. Dari kristalisasi fraksi ke-5 dengan menggunakan pelarut $\mathrm{MeOH}$ dihasilkan senyawa brusein-A, kemudian dilakukan analisis spektroskopi. Prosedur ekstraksi dan isolasi senyawa brusein-A dari buah makasar dapat dilihat pada Gambar 1.

Pengujian aktivitas antiproliferasi senyawa brusein-A dari buah makasar secara in vitro dilakukan memakai sel T47D metode Rachmani dkk. ${ }^{1}$ Sel kanker payudara T47D merupakan continous cell lines yang morfologinya seperti sel epitel yang diambil dari jaringan payudara seorang wanita berusia 54 tahun yang terkena ductal carcinoma. Sel ini termasuk cell line adherent ATCC yang mengekspresikan ER- $\beta$ dibuktikan dengan terjadi respons peningkatan proliferasi yang merupakan akibat pemaparan $17 \beta$-estradiol. ${ }^{13,14}$ Sel ini memiliki doubling time 32 jam dan diklasifikasikan sebagai sel yang mudah mengalami diferensiasi karena memiliki 


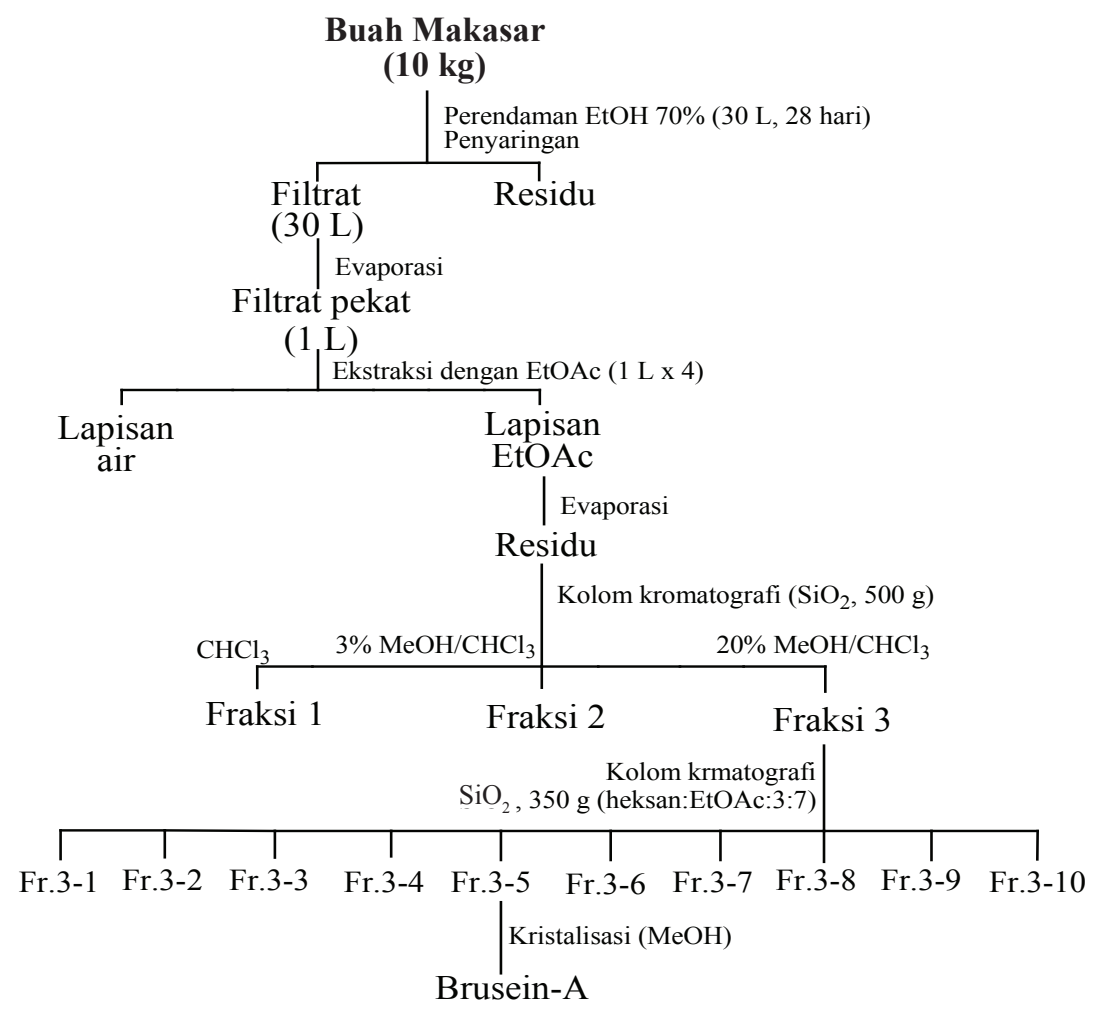

\section{Gambar 1 Prosedur Ekstraksi dan Isolasi Senyawa Brusein-A dari Buah Makasar}

reseptor estrogen+15 Sel ini sensitif terhadap doxorubicin dan mengalami missense mutation pada residu 194 dalam zinc binding domain L2 gen $p 53 .^{13}$ Loop L2 ini berperan penting pada pengikatan DNA dan stabilisasi protein. Jika $p 53$ tidak dapat berikatan dengan response element pada DNA, kemampuannya untuk regulasi cell cycle dapat berkurang atau hilang. ${ }^{16}$ Pada sel tumor dengan mutasi p53 diketahui terjadi pengurangan respons terhadap agen-agen yang menginduksi apoptosis dan juga tumor tersebut kemungkinan menjadi resisten terhadap obat antineoplastik yang memiliki target pengrusakan DNA. ${ }^{17}$

Sel T47D (koleksi Laboratorium Puslit Kimia, LIPI, Bandung) ditumbuhkan dalam suatu media Dulbecco's Modified Eagle Medium (DMEM). Media DMEM sebanyak 12 g dilarutkan dalam 1 $\mathrm{L}$ akuades steril dan ditambahkan 3,7 $\mathrm{g} \mathrm{NaHCO}_{3}$, gentamisin $1 \%$, penisilin $10.000 \mathrm{IU}$, serta $\mathrm{pH}$ diatur 7,2. Media selanjutnya ditambahkan 10\% fetal bovine serum (FBS) dan disterilisasi dengan membran filter $0,22 \mu \mathrm{m}$.

Pemeliharaan sel T47D dilakukan dengan mengganti media kultur setiap 3 hari dengan cara suspensi sel dari flask culture dipindahkan ke dalam tabung dan disentrifus dengan kecepatan $1.000 \mathrm{rpm}$ selama 10 menit. Supernatan lalu dibuang dan sel yang mengendap dicuci dengan larutan phosphate buffer saline (PBS) dan juga disentrifius dengan kecepatan 1.000 rpm selama 10 menit. Sesudah itu endapan ditambahkan media baru sebanyak $5 \mathrm{~mL}$ serta dimasukkan ke dalam flask culture dan diinkubasi dalam inkubator $\mathrm{CO}_{2}$ pada suhu $37^{\circ} \mathrm{C}, 5 \% \mathrm{CO}_{2}$, dengan kelembaban relatif $95 \%$ selama 3 hari.

Setelah diinkubasi, sel T47D dicuci dengan larutan PBS sebanyak 5 mL. Selanjutnya, ke dalam flask culture yang berisi sel T47D ditambahkan 0,025\% larutan tripsin-EDTA sebanyak $100 \mathrm{~mL}$ dan FBS $900 \mathrm{~mL}$ dan diinkubasi dalam inkubator $\mathrm{CO}_{2}$ pada suhu $37^{\circ} \mathrm{C}, 5 \% \mathrm{CO}_{2}$, dengan kelembaban relatif 95\% selama 15 menit. Lalu, ditambahkan $1 \mathrm{~mL}$ media baru dan dilakukan perhitungan sel dengan hemositometer.

Pembuatan master plate untuk pengujian antiproliferasi dengan mempergunakan 96-well microplate. Well A-B untuk sampel brusein-A dan 
C-D untuk standar obat cisplatin. Well 1 sampai 10 diisi oleh sampel brusein-A atau cisplatin dari berbagai konsentrasi. Pembuatan konsentrasi brusein-A atau cisplatin dilakukan dengan cara ke dalam well A-D pada posisi No. 1 diisi dengan $180 \mathrm{~mL}$ akuades steril. Selanjutnya, ke dalam well No. 1 tambahkan 20 mL brusein-A atau cisplatin yang dilarutkan dalam dimethyl sulfoxide (DMSO) dengan konsentrasi $20 \mathrm{mg} / \mathrm{mL}$. Lalu, dari well No. 1 tersebut diambil $100 \mathrm{~mL}$ dan dimasukkan ke dalam well No. 2 dan ditambahkan $100 \mathrm{~mL}$ akuades steril sampai seterusnya hingga No. 10 sehingga diperoleh konsentrasi brusein- $\mathrm{A}$ atau cisplatin sebesar $0,04 \mathrm{mg} / \mathrm{mL}$.

Pengujian antiproliferasi dilakukan dengan cara memasukkan $10 \mathrm{~mL}$ larutan dari master plate dalam setiap 96-well microplate baru No. 1-10 diisi dengan sesuai dengan urutan pada master plate tersebut. Selanjutnya, ke dalam setiap well ditambahkan $190 \mathrm{~mL}$ kultur T47D yang mengandung sel sebanyak 30.000. Well E-F diisi dengan 10 mL DMSO 10\% dan 190 mL kultur sel T47D sebagai kontrol positif efek penggunaan DMSO untuk melarutkan brusein-A dan cisplatin terhadap pertumbuhan sel. Pembuatan zero day cell dilakukan dengan cara ke dalam well G-H diisi dengan $10 \mathrm{~mL}$ akuades steril dan $190 \mathrm{~mL}$ kultur sel T47D sebagai kontrol negatif. Selanjutnya, microplate diinkubasi dalam inkubator $\mathrm{CO}_{2}$ pada suhu $37^{\circ} \mathrm{C}, 5 \% \mathrm{CO}_{2}$ dengan kelembaban relatif 95\% selama 72 jam.

Pengamatan efek antiproliferasi senyawa brusein-A dan cisplatin terhadap sel T47D diukur absorbansinya menggunakan ELISA reader pada panjang gelombang $515 \mathrm{~nm}$. Pada konsentrasi senyawa uji yang lebih kecil ditemukan pada morfologi sel yang masih hidup sehingga dengan pewarnaan SRB pada media kultur memberikan warna hijau. Pada konsentrasi senyawa uji yang lebih besar dapat menyebabkan apoptosis dengan terjadi fragmentasi DNA dan kondensasi kromatin pada nukleus sel sehingga media kultur berwarna oranye. Rumus penghitungan persentase viabilitas sel T47D pada setiap konsentrasi brusein-A dan cisplatin ditentukan sebagai berikut:

Viabilitas (\%)= $\frac{\text { ODss }- \text { ODzd }}{\text { ODsd }- \text { ODzd }} \times 100$

Keterangan:

$\mathrm{OD}_{\mathrm{ss}}$ : optical density (sel + sampel)

$\mathrm{OD}_{\mathrm{zd}}$ : optical density (zero day)

$\mathrm{OD}_{\mathrm{sd}}^{\mathrm{zd}}$ : optical density (sel + DMSO 10\%)

Data dihitung sebagai nilai $\mathrm{IC}_{50}$ yang merupakan konsentrasi larutan uji yang dapat mematikan $50 \%$ populasi sel. Data disajikan dalam bentuk grafik dan dianalisis secara deskriptif.

\section{Hasil}

Uji sitotoksik secara in vitro digunakan untuk mengetahui aktivitas antiproliferatif senyawa yang diuji dengan nilai $\mathrm{IC}_{50}$. Nilai $\mathrm{IC}_{50}$ adalah konsentrasi senyawa uji yang dapat mematikan sebanyak $50 \%$ populasisel.Semakin kecil nilai IC ${ }_{50}$

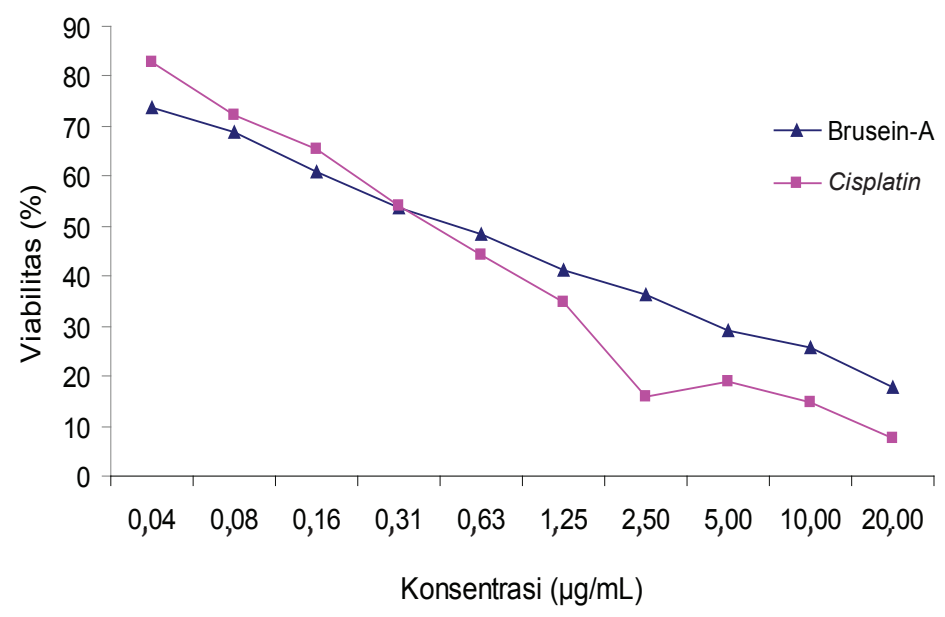

Gambar 2 Pengaruh Senyawa Brusein-A dari Buah Makasar dan Cisplatin terhadap Viabilitas Sel Kanker Payudara T47D 


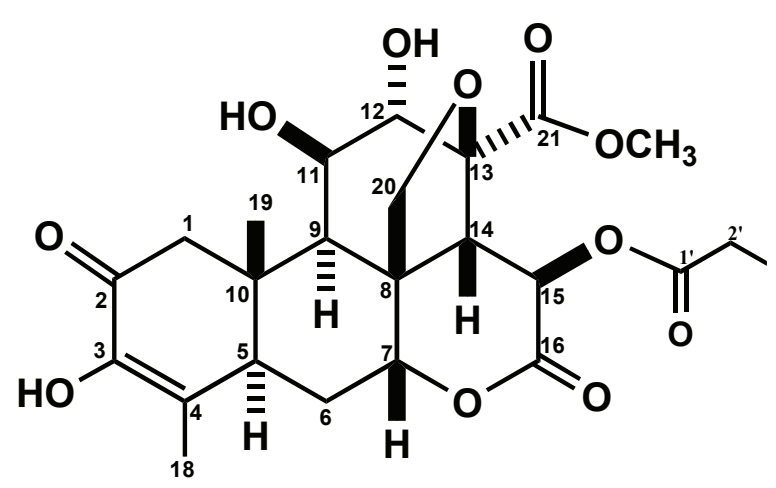

\section{Gambar 3 Struktur Kimia Brusein-A dari Buah Makasar}

menunjukkan potensi senyawa tersebut sebagai obat kanker semakin besar. Hasil penelitian ini menunjukkan bahwa terdapat korelasi jumlah sel kanker payudara T47D yang mati dengan kenaikan konsentrasi brusein-A. Perbedaan pada konsentrasi brusein-A menyebabkan perbedaan viabilitas sel kanker payudara. Semakin besar konsentrasi brusein-A yang ditambahkan dalam media kultur, maka semakin kecil viabilitas sel kanker payudara (Gambar 2).

Penggunaan senyawa brusein-A dari buah makasar pada konsentrasi $20 \mu \mathrm{g} / \mathrm{mL}$ mempunyai nilai viabilitas terendah yaitu 17,93\%, sedangkan pada konsentrasi $0,04 \mu \mathrm{g} / \mathrm{mL}$ mempunyai nilai viabilitas tertinggi yaitu 73,85\%. Nilai viabilitas sel kanker payudara pada konsentrasi brusein-A $10 ; 5 ; 2,5 ; 1,25 ; 0,63 ; 0,31 ; 0,16$; dan $0,08 \mu \mathrm{g} /$ mL secara berurutan sebesar 25,60\%, 29,15\%, $36,20 \%, 41,18 \%, 48,36 \%, 53,74 \%, 60,71 \%$, dan $68,96 \%$. Keadaan yang sama juga terjadi pada standar obat antikanker cisplatin. Cisplatin pada konsentrasi $20 \mu \mathrm{g} / \mathrm{mL}$ mempunyai nilai viabilitas terendah yaitu 7,50\%, sedangkan pada konsentrasi $0,04 \mu \mathrm{g} / \mathrm{mL}$ memiliki nilai viabilitas tertinggi yaitu $82,72 \%$. Nilai viabilitas sel kanker payudara pada konsentrasi cisplatin $10 ; 5 ; 2,5$; 1,$25 ; 0,63 ; 0,31 ; 0,16$; dan $0,08 \mu \mathrm{g} / \mathrm{mL}$ secara berurutan sebesar 14,85\%, 18,93\%, 15,97\%, $34,83 \%, 44,18 \%, 54,10 \%, 65,37 \%$, dan $72,26 \%$.

\section{Pembahasan}

Senyawa brusein-A yang diisolasi dari buah makasar mempunyai bentuk tepung amorphous dengan titik lebur $271-272^{\circ} \mathrm{C}$ dengan nilai optikal rotasi $[\mathrm{a}]_{\mathrm{D}}^{20}-80,3^{\circ}(\mathrm{c} 0,8$, piridin). Analisis dengan IR menunjukkan gugus hidroksi (3.420 $\left.\mathrm{cm}^{-1}\right)$, d-lakton and ester $\left(1.736 \mathrm{~cm}^{-1}\right)$, serta a,b-karbonil ikatan rangkap (1.683 dan 1.640 $\mathrm{cm}^{-1}$ ). Hasil analisis Mass Spectrometer FD-MS: $m / z \quad 522 \quad[\mathrm{M}]^{+}$dan HR-EI-MS $m / z \quad 522.2090$ $[\mathrm{M}]^{+}$menunjukkan rumus molekul $\mathrm{C}_{26} \mathrm{H}_{34} \mathrm{O}_{11}$. Analisis proton ${ }^{1} \mathrm{H}-\mathrm{NMR}$ menunjukkan spektrum resonansi satu metil tersier $(\mathrm{d} 1,22)$, dua metil sekunder (d 0,90 dan 0,91), dan satu metil olefinik ( $d 1,72)$, sedangkan analisis karbon ${ }^{13}$ C-NMR memberikan spektrum resonansi pada C-3 ( $\delta$ 144,2), C-11 ( $\delta 71,5)$, dan C-12 ( $\delta 74,7)$. Keadaan ini menunjukkan bahwa terdapat gugus hidroksi yang terikat pada karbon. Berdasarkan hasil analisis ${ }^{13} \mathrm{C}-\mathrm{NMR}$ (d 170,0; 42,6; 25,4; 22,3, dan 22,4) rantai samping mengandung gugus 3-methylbutanoyloxy yang berhubungan dengan C-15. ${ }^{12}$ Struktur kimia senyawa brusein-A dari buah makasar dapat dilihat pada Gambar 3.

Brusein-A merupakan quasinoid golongan triterpen yang berperan sebagai antikanker., Sebagai antikanker, senyawa brusein-A memiliki kemampuan berikatan dengan DNA sehingga memengaruhi gen $c$-Myc dan dapat menginduksi apoptosis. Selain itu, senyawa brusein-A juga dapat menghambat nuclear factor kappa $B$ (NF$\kappa \mathrm{B})$. Dengan demikian dapat dikatakan bahwa ekstrak buah makasar memiliki aktivitas sebagai antiproliferatif maupun proapoptosis terhadap karsinoma. Efek sitotoksik ekstrak buah makasar dapat menyebabkan fragmentasi DNA sehingga menyebabkan apoptosis. ${ }^{9-11}$

Apoptosis adalah mekanisme biologi yang merupakan salah satu jenis kematian sel yang terprogram. Apoptosis dipergunakan oleh suatu organisme multisel untuk membuang sel yang tidak diperlukan oleh tubuh. Salah satu fungsi apoptosis adalah untuk membatasi proliferasi sel yang tidak diperlukan tubuh yang mampu menyebabkan kanker. Secara umum, beberapa tahapan apoptosis mulai dari fragmentasi DNA, penyusutan sitoplasma, dan terjadi perubahan membran yang diikuti oleh kematian sel tanpa lisis atau tanpa merusak sel tetangga. ${ }^{18}$

Brusein-A yang diisolasi dari buah makasar memiliki kemampuan untuk menghambat enzim DNA topoisomerase II yang berfungsi dalam proses replikasi, transkripsi, rekombinasi, dan proliferasi sel kanker. Penghambatan aktivitas enzim tersebut akan membentuk protein linked DNA breaks (PLDB) yang dapat menyebabkan fragmentasi DNA sel kanker dan selanjutnya berpengaruh pada proses replikasi sel kanker. ${ }^{19,20}$ Zhang dkk. ${ }^{21}$ mengemukakan bahwa apoptosis melibatkan mekanisme yang kompleks, baik melalui jalur mitokondria, reseptor kematian, maupun survival.

Ketiga jalur tersebut melibatkan regulator 
caspase-8 ataupun caspase-9. Apoptosis melalui caspase- 9 biasanya melibatkan gen $p 53$ seperti pada kematian sel kanker mieloma, sementara pada sel kanker T47D dapat menyebabkan kehilangan fungsi gen $p 53^{10,22,23}$ Gen $p 53$ yang hilang di dalam sel kanker karena mengalami mutasi pada residu 194, leusin berubah menjadi fenilalanin. Akibatnya, gen $p 53$ akan merangsang mitokondria melepaskan sitokrom-c ke dalam sitosol. Di dalam sitosol, sitokrom-c bersama dengan apoptotic protease activating factor 1 (APAF1) dan procaspase-9 akan membentuk caspase-9. Selanjutnya, pembentukan caspase-9 sebagai caspase awal akan mengaktifkan caspase eksekusioner caspase-3, -6, dan -7 sehingga menyebabkan apoptosis sel. ${ }^{10,23}$

Data yang diperoleh dari berbagai konsentrasi brusein-A kemudian dianalisis dengan regresi linier sehingga dihasilkan nilai IC $_{50}$. Hasil analisis menunjukkan hubungan yang sangat erat antara persentase kematian sel kanker payudara T47D dan konsentrasi senyawa brusein-A. Hal ini terlihat dari nilai koefisien korelasi sebesar 0,996 . Senyawa brusein-A dari buah makasar pada konsentrasi $0,54 \mu \mathrm{g} / \mathrm{mL}$ dapat menghambat $50 \%$ proliferasi sel kanker payudara $\left(\mathrm{IC}_{50}\right)$. Nilai IC ${ }_{50}$ dari senyawa brusein-A ini tidak jauh berbeda dengan nilai $\mathrm{IC}_{50}$ standar obat cisplatin yaitu sebesar $0,43 \mu \mathrm{g} / \mathrm{mL}$ dengan koefisien korelasi sebesar 0,967 .

Buah makasar telah dipergunakan secara tradisional oleh masyarakat untuk mengatasi berbagai penyakit, termasuk penyakit kanker. Pada penelitian ini dapat dibuktikan secara in vitro bahwa senyawa brusein-A yang diisolasi dari buah makasar mampu menimbulkan efek antiproliferasi pada sel kanker payudara T47D. Diperlukan penelitian lebih lanjut baik secara in vivo dan uji klinik sebagai dasar penggunaan brusein-A sebagai obat antikanker.

\section{Daftar Pustaka}

1. Rachmani EPN, Suhesti S, Widiastuti R, Aditiyono. The breast of anticancer from leaf extract of Annona muricata againts cell line in T47D. Int J Applied Sci Technol. 2012; 2(1):157-64.

2. Jemal J, Freddie BF, Center MM, Ferlay J, Ward E, Forman D. Global cancer statistics. Ca Cancer J Clin. 2011;61:69-90.

3. Ng CH, Pathy NB, Taib NA, Teh YC, Mun KS, Amiruddin A, dkk. Comparison of breast cancer in Indonesia and Malaysia clinicopathological study between Dharmais
Cancer Centre Jakarta and University Malaya Medical Centre, Kuala Lumpur. Asian Pac J Cancer Prev. 2011;12:2943-6.

4. Aryandono T, Harijadi S. Survival from operable breast cancer: prognostic factors in Yogyakarta, Indonesia. Asian Pac J Cancer Prev. 2006;7:455-9.

5. Avril N, Sassen S, Roylance R. Response to therapy in breast cancer. J Nucl Med. 2009;50:55-63S.

6. Rapoport NY, Kennedy AM, Shea JE, Scaife CL, Nam KH. Controlled and targeted tumor chemotherapy by ultrasound activated nano emulsions/ microbubbles. J Control Release. 2009;138(3):268-76.

7. Tian GY, Xie RH. Experimental study on the anticancer effect of extract of Brucea javanica on mice of S180. Antitumor Pharmacy. 2011;1(3):220-2.

8. Yang LH, Shi WJ, Zhao XQ. Research progress on the anti-tumor effect of Brucea javanica. J Mudanjiang Univ. 2010;31(5):65-7.

9. Lau ST, Lin ZX, Zhao M, Leung PS. Brucea javanica fruit induces cytotoxicity and apoptosis in pancreatic adenocarcinoma cell lines. Phytother Res. 2008;22(4):477-86.

10. Lou GG, Yao HP, Xie LP. Brucea javanica oil induces apoptosis in T24 bladder cancer cells via upregulation of caspase-3, caspase-9, and inhibition of NF-kappaB and COX-2 expressions. Am J Chin Med. 2010;38(3):613-24.

11. Kim JA, Lau EK, Pan L, de Blanco EJC. NF-кB inhibitors from Brucea javanica exhibiting intracellular effects on reactive oxygen species. Anticancer Res. 2010;30(9):3295300.

12. Subeki, Matsuura H, Yamasaki M, Yamato O, Maede Y, Nabeta K, dkk. Screening of some Indonesian medicinal plants for antibabesial activity and isolation of new quassinoids from Brucea javanica. J Nat Prod. 2007;70:1654-7.

13. Zampieri L, Bianchi P, Ruff P, Arbuthnot P. Differential modulation by estradiol of P-glycoprotein drug resistance protein expression in cultured MCF7 and T47D breast cancer cells. Anticancer Res. 2002; 22(4):2253-9.

14. Verma SP, Goldin BR, Lin PS. The inhibition of the estrogenic effects of pesticides dan enviromental chemicals by curcumin and isoflavonoids. Envir Health Presp. 1998;106(12):807-12.

15. Wozniak MA, Keely PJ. Use of three dimensional collagen gels to study 
mehanotransduction in T47D breast epitelial cells. Biomed Life Sci. 2005;7:144-61.

16. Schafer JM, Lee ES, O’Regan RM, Yao K, Jordan VC. Rapid development of tamoxifenstimulated mutant p53 breast tumors (T47D) in athymic mice. Clin Cancer Research. 2000;6:4373-80.

17. Crawford KW, Bowen WD. Sigma-2 receptor angonists activate a novel apoptotic pathway and potentiate antineoplastic drugs in breast tumor cell lines. Cancer Research. 2002;62:313-22.

18. Hahm HA. Davidson NE. Apoptosis in the mammary gland and breast cancer. Endocrine Related Cancer. 1998;5:199-211.

19. Sabourin M, Nitiss JL, Nitiss KC, Tatebayashi $\mathrm{K}$, Ikeda H, Osheroff N. Yeast recombination pathways triggered by topoisomerase II-mediated DNA breaks. Nucleic Acids Research. 2003;31(15):437-8.

20. Tian CT, Han LY. Inhibition of Brucea javanica oil emulsion on the proliferation of human liver cancer cell SMMC-7721 cells in vitro. Modern Oncol. 2010;18(4):654-5.

21. Zhang H, Yang JY, Zhou F. Seed oil of Brucea javanica induces apoptotic death of acute myeloid leukemia cells via both the death receptors and the mitochondrial-related pathways. Evid Based Complement Alternat Med. 2011:965-76.

22. Rosati A, Quaranta E, Ammirante M, Turco MC, Leone A, De Feo V. Quassinoids can induce mitochondrial membrane depolarisation and caspase 3 activation in human cells. Cell Death Differ. 2004;11(2):S216-8.

23. Ooi MG, Hayden PJ, Kotoula V, Mc Millin DW, Charalambous E, Daskalaki E, dkk. Interactions of the $\mathrm{Hdm} 2 / \mathrm{p} 53$ and proteasome pathways may enhance the antitumor activity of bortezomib. Clin Cancer Res. 2009;15(23):7153-60. 